\title{
Current trends in the management of acute appendicitis
}

\author{
S. Ng · F. J. Fleming $\cdot$ M. O'Connor · J. Drumm \\ D. Waldron $\cdot$ P. A. Grace
}

Published online: 5 August 2008

(C) Royal Academy of Medicine in Ireland 2008

Erratum to: Ir J Med Sci (2008) 177:121-125

DOI 10.1007/s11845-008-0116-4

The submitting author omitted the name of a co-author. The complete list of authors should read:

S. Ng · F. J. Fleming · M. O'Connor · J. Drumm ·

D. Waldron · P. A. Grace

The online version of the original article can be found under doi: 10.1007/s11845-008-0116-4.

S. Ng · F. J. Fleming · M. O'Connor · J. Drumm - D. Waldron ·

P. A. Grace $(\square)$

Department of Surgery,

Mid-Western Regional Hospital, Limerick, Ireland

e-mail: pagrace@eircom.net

F. J. Fleming

e-mail: fergalfleming@gmail.com

P. A. Grace

University of Limerick, Limerick, Ireland 